\title{
Radiotherapy as Elective Treatment of the Node-negative Neck in Oral Squamous Cell Cancer
}

\author{
ERIK LUNDIN ${ }^{1,2}$, JOHAN REIZENSTEIN ${ }^{2}$, FREDRIK LANDSTROM ${ }^{1,3}$, \\ MICHAEL BERGQVIST $^{4,5}$, BO LENNERNAS ${ }^{6}$ and JOHAN AHLGREN ${ }^{1,7}$ \\ ${ }^{1}$ Institution for Medical Sciences, Örebro University, Örebro, Sweden; \\ ${ }^{2}$ Department of Oncology, Örebro University Hospital, Örebro, Sweden; \\ ${ }^{3}$ Department of Otorhinolaryngology, Örebro University Hospital, Örebro, Sweden; \\ ${ }^{4}$ Department of Radiation Sciences, Umeå University, Umeå, Sweden; \\ ${ }^{5}$ Department of Oncology, CFUG, Gävle Hospital, Gävle, Sweden; \\ ${ }^{6}$ Department of Oncology, Karolinska Institute, Stockholm, Sweden; \\ ${ }^{7}$ Regional Oncological Centre Mid-Sweden, Uppsala, Sweden
}

\begin{abstract}
Background/Aim: Previous studies of nodenegative oral squamous cell carcinoma have shown a benefit of elective neck dissection compared to observation. Evidence for radiotherapy as single-modality elective treatment of the node-negative neck is so far lacking. Patients and Methods: In a retrospective material of 420 early-stage oral cancers from 2000 to 2016, overall survival, disease-free survival, and regional relapse-free survival were calculated with the Kaplan-Meier method. Results: At five years, overall survival was $59.7 \%$, disease-specific survival was $77.2 \%$, and regional relapse-free survival was $83.5 \%$. Among those with adjuvant treatment of the neck after surgery of T1-T2 tumours during 2009-2016, regional relapse-free survival at five years was $85.7 \%$ for elective radiotherapy of the neck and $87.4 \%$ for elective neck dissection. Conclusion: Elective radiotherapy to the neck with a modern technique and adequate dose might be an alternative to neck dissection for patients with early-stage oral squamous cell cancer.
\end{abstract}

The standard treatment of oral squamous cell carcinoma (OSCC) is surgery with adequate resection margins, with or

This article is freely accessible online.

Correspondence to: Erik Lundin, Onkologkliniken, USÖ, 70185 Örebro, Sweden. Tel: +46 196021389, e-mail: erik.lundin@ regionorebrolan.se

Key Words: Head and neck cancer, oral cancer, adjuvant radiotherapy, radiotherapy, neck dissection, squamous cell carcinoma, quality register. without adjuvant radiotherapy. In clinically node-negative (cN0) cases, the frequency of subclinical nodal metastases ranges from about $16 \%$ to $26 \%$ (1-3). There are currently four ways to manage the neck in patients with cNO OSCC: watchful waiting, elective neck dissection (END), elective radiotherapy of the neck (ERTN), and a combination of END and ERTN (4). The role of post-operative radiotherapy to the primary tumour site remains undetermined, although some evidence suggests that it reduces the risk of locoregional failure $(5,6)$. END has been shown to increase disease-free survival at three years from $45.9 \%$ to $69.5 \%$ and overall survival (OS) at three years from $67.5 \%$ to $80.0 \%$ in patients with early stage OSCC when compared to watchful waiting (7). However, the effectiveness of ERTN in this group has been only sparsely studied.

END is associated with several complications such as nerve damage, seroma, and infections, which can be avoided by replacing END with ERTN. An argument for performing an END concurrently with resection of the primary tumour is to keep the total treatment time as short as possible. However, as ERTN can be administered alongside postoperative radiotherapy to the primary tumour site, it will not prolong the total treatment, but instead give the opportunity to decide on the need for adjuvant treatment of the neck when the pathology report from the surgery of the primary tumour is available $(5,8-14)$. At the Head and Neck Oncology Centre of the University Hospital in Örebro, the routine treatment of $\mathrm{cNO}$ OSCC has been to use ERTN as the single adjuvant neck treatment, and to do END only in connection with free flap reconstructive surgery.

A quality register has been kept since 1988, continuously collecting data on all head and neck cancer patients receiving any treatment at Örebro University Hospital in Sweden, 
Table I. Fractionation schedules used in radiotherapy.

\begin{tabular}{|c|c|c|c|c|c|c|}
\hline Fractionation schedule & Fractions & $\begin{array}{l}\text { Total dose to } \\
\text { postoperative } \\
\text { volumes with } \\
\text { clear margin }\end{array}$ & $\begin{array}{c}\text { Total dose to } \\
\text { postoperative } \\
\text { volumes with } \\
\text { positive or close } \\
\text { margin }\end{array}$ & $\begin{array}{c}\text { Total dose to } \\
\text { elective } \\
\text { volumes }\end{array}$ & $\begin{array}{c}\text { Number of } \\
\text { patients treated, } \\
2000-2008\end{array}$ & $\begin{array}{c}\text { Number of } \\
\text { patients treated, } \\
2009-2016\end{array}$ \\
\hline Conventional fractionation & 2 Gy daily & $60 \mathrm{~Gy}$ & $66-68 \mathrm{~Gy}$ & $50-60 \mathrm{~Gy}^{\mathrm{a}}$ & 18 & 107 \\
\hline Hyper-fractionation & 1.7 Gy twice daily & $57.8 \mathrm{~Gy}$ & 64.6-68 Gy & $40.8 \mathrm{~Gy}$ & 70 & 1 \\
\hline $\begin{array}{l}\text { Hyperfractionation } \\
\text { with concomitant boost }\end{array}$ & $\begin{array}{l}2 \text { Gy daily to all } \\
\text { target volumes }+ \\
1.1 \text { Gy daily to } \\
\text { boost volumes }\end{array}$ & $59.2-60.3 \mathrm{~Gy}$ & 68 Gy & 46-50 Gy & 6 & $12^{\mathrm{b}}$ \\
\hline
\end{tabular}

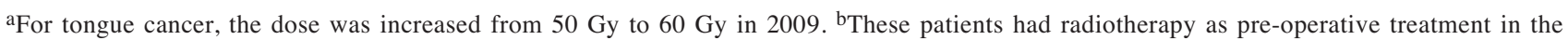
randomized ARTSCAN II study.

including follow-up data for five years after treatment. As head and neck cancer patients are referred from several neighbouring counties in central Sweden, the uptake area has nearly 1.7 million inhabitants, and at the time of writing the register contained data on 5,500 cases of head and neck cancer. This gives a unique opportunity to perform retrospective analysis of the treatments given at the centre.

The aim of this study was to evaluate the effectiveness of treatment with ERTN as the single adjuvant treatment for the node-negative neck in OSCC, and thus to determine if END can be omitted in favour of ERTN. This was achieved by analysing whether there is a benefit in regional relapse-free survival (rRFS), disease-specific survival (DSS), or OS for patients who had END compared to patients who had ERTN only. There is almost certainly a bias in the selection between ERTN and END, therefore no firm conclusions on the superiority or non-inferiority of either strategy can be drawn from this study. However, due to the scarcity of outcome data on ERTN only, this study should be of interest.

\section{Patients and Methods}

The register. The quality register at the Head and Neck Oncology Centre of Örebro University Hospital in Sweden contains information about the diagnosis, treatment, and outcome of patients treated at the centre (15). Medical information was retrieved for every patient who died during the first five years after treatment, to establish as accurately as possible whether there were any manifestations of cancer at the time of death. From the beginning, the register has been maintained by one oncologist and two head and neck surgeons, ensuring continuity in the registration. For deceased patients, exact time of death was retrieved from the highly reliable Swedish population register.

After data for all OSCC patients treated with curative intent between 1 January 2000 and 30 June 2016 were extracted from the register, a validation study was performed to assess the quality of the data. This showed that data on diagnosis and treatment were highly accurate, while data on recurrences were missing in $23 \%$ of cases and contained errors in $22 \%$ (15). In order to correct these errors in the register, data on recurrences were collected from medical records, along with data concerning tumour thickness and surgical margin that were not originally included in the register.

Patients and procedures. Örebro University Hospital is a regional centre for the treatment of head and neck cancer. Diagnostic workup was mostly performed at the referring hospital and then reviewed and completed at the Head and Neck Oncology Centre at Örebro University Hospital. Staging was based on clinical examination and CT scan; during the study period, this was done according to the AJCC TNM 7 (16). When diagnostic work-up was complete, all cases were discussed at a tumour board where treatment was decided in accordance with regional guidelines.

All oncological and reconstructive surgery was performed at Örebro University Hospital. The standard treatment of node-negative OSCC according to local guidelines was surgical resection of the primary tumour, which in all but the very low-risk cases was followed by adjuvant radiotherapy of the primary tumour site and the neck. However, in cases where free flap reconstructive surgery was required, an elective neck dissection was performed concurrently with the vascular access procedure. In node-negative cases without free flap reconstruction, neck dissection was not generally performed. The principles for treatment of OSCC at Örebro University Hospital have remained mostly unchanged during the last two decades.

After surgery, the cases were again discussed at the tumour board to decide on postoperative radiotherapy for patients considered at risk of relapse. This decision was based mainly on resection margins, tumour size, and tumour thickness, but other factors such as perineural invasion were also considered, as well as the age and overall health of the patient. Radiotherapy was administered either in Örebro or in a hospital closer to the patient's home. In all cases, the recommended radiation dose and target volumes were decided at the tumour board. When radiotherapy was administered in another hospital, data on the treatment were retrieved from that clinic to ensure that the register data were accurate.

In selected cases, surgery of the primary lesion was replaced with full-dose brachytherapy, electro-chemotherapy $(17,18)$, photodynamic therapy, or full-dose external radiotherapy. The choice of elective treatment of the neck followed the same guidelines regardless of the treatment for the primary site. END was 
Table II. Baseline characteristics and primary treatment.

\begin{tabular}{|c|c|c|c|c|c|c|}
\hline \multirow[b]{3}{*}{ Total number of cases } & \multicolumn{2}{|c|}{ Complete cohort } & \multicolumn{4}{|c|}{ Cases with elective neck treatment } \\
\hline & & & \multicolumn{2}{|c|}{ END } & \multicolumn{2}{|c|}{ ERTN only } \\
\hline & 420 & & 137 & & 129 & \\
\hline Mean age in years & 68 & & 68 & & 64 & \\
\hline Median age in years & 69 & & 70 & & 66 & \\
\hline \multicolumn{7}{|l|}{ Gender } \\
\hline Female & 211 & $(50.2 \%)$ & 65 & $(47.4 \%)$ & 57 & $(44.2 \%)$ \\
\hline Male & 209 & $(49.8 \%)$ & 72 & $(52.6 \%)$ & 72 & $(55.8 \%)$ \\
\hline \multicolumn{7}{|l|}{ Tumour location } \\
\hline Inside of lip & 6 & $(1.4 \%)$ & 1 & $(0.7 \%)$ & 0 & $(0 \%)$ \\
\hline Tongue & 189 & $(45 \%)$ & 34 & $(24.8 \%)$ & 87 & $(67.4 \%)$ \\
\hline Gingiva & 116 & $(27.6 \%)$ & 63 & $(46 \%)$ & 22 & $(17.1 \%)$ \\
\hline Floor of mouth & 64 & $(15.2 \%)$ & 25 & $(18.2 \%)$ & 15 & $(11.6 \%)$ \\
\hline Hard palate & 2 & $(0.5 \%)$ & 0 & $(0 \%)$ & 1 & $(0.8 \%)$ \\
\hline Bucca & 43 & $(10.2 \%)$ & 14 & $(10.2 \%)$ & 4 & $(3.1 \%)$ \\
\hline \multicolumn{7}{|l|}{ T-stage } \\
\hline $\mathrm{T} 1-\mathrm{T} 2$ & 298 & $(70.9 \%)$ & 61 & $(44.5 \%)$ & 101 & $(78.3 \%)$ \\
\hline $\mathrm{T} 3-\mathrm{T} 4$ & 122 & $(29.1 \%)$ & 76 & $(55.5 \%)$ & 28 & $(21.7 \%)$ \\
\hline \multicolumn{7}{|l|}{ Surgical margin } \\
\hline Clear & 254 & $(60.5 \%)$ & 96 & $(75.0 \%)$ & 54 & $(58.1 \%)$ \\
\hline Close & 47 & $(11.2 \%)$ & 16 & $(12.5 \%)$ & 19 & $(20.4 \%)$ \\
\hline Positive & 36 & $(8.6 \%)$ & 15 & $(11.7 \%)$ & 12 & $(12.9 \%)$ \\
\hline Unknown & 83 & $(19.7 \%)$ & 1 & $(0.8 \%)$ & 8 & $(8.6 \%)$ \\
\hline \multicolumn{7}{|l|}{ Tumour thickness in tongue cancer } \\
\hline$<5 \mathrm{~mm}$ & 32 & $(16.9 \%)$ & 3 & $(8.8 \%)$ & 14 & $(16.1 \%)$ \\
\hline $5-9.9 \mathrm{~mm}$ & 46 & $(24.3 \%)$ & 9 & $(26.5 \%)$ & 22 & $(25.3 \%)$ \\
\hline$\geq 10 \mathrm{~mm}$ & 28 & $(14.8 \%)$ & 10 & $(29.4 \%)$ & 13 & $(14.9 \%)$ \\
\hline Unknown & 83 & $(43.9 \%)$ & 12 & $(35.3 \%)$ & 38 & $(43.7 \%)$ \\
\hline \multicolumn{7}{|l|}{ Treatment of primary tumour site } \\
\hline Surgery & 339 & $(80.7 \%)$ & 131 & $(95.6 \%)$ & 86 & $(66.7 \%)$ \\
\hline Brachytherapy & 49 & $(11.7 \%)$ & 5 & $(3.6 \%)$ & 25 & $(19.4 \%)$ \\
\hline ECT & 17 & $(4.0 \%)$ & 1 & $(0,7 \%)$ & 10 & $(7.8 \%)$ \\
\hline PDT & 8 & $(1.9 \%)$ & 0 & $(0 \%)$ & 2 & $(1.6 \%)$ \\
\hline External radiotherapy & 6 & $(1.4 \%)$ & 0 & $(0 \%)$ & 6 & $(4.7 \%)$ \\
\hline No treatment given & 1 & $(0.2 \%)$ & 0 & $(0 \%)$ & 0 & $(0 \%)$ \\
\hline \multicolumn{7}{|l|}{ Adjuvant treatment of neck } \\
\hline END- ERTN- & 154 & $(36.7 \%)$ & 0 & $(0 \%)$ & 0 & $(0 \%)$ \\
\hline END- ERTN+ & 129 & $(30.7 \%)$ & 0 & $(0 \%)$ & 129 & $(100 \%)$ \\
\hline END+ ERTN- & 45 & $(10.7 \%)$ & 45 & $(32.8 \%)$ & 0 & $(0 \%)$ \\
\hline END+ ERTN+ & 92 & $(21.9 \%)$ & 92 & $(67.2 \%)$ & 0 & $(0 \%)$ \\
\hline Chemotherapy concurrent with ERTN & 8 & $(1.9 \%)$ & 4 & $(2.9 \%)$ & 4 & $(3.1 \%)$ \\
\hline
\end{tabular}

ECT: Electrochemotherapy; PDT: photodynamic therapy; ERTN: elective radiotherapy of the neck; END: elective lymph node dissection.

only performed for a few of these patients, whereas ERTN was administered to patients with high risk of recurrence.

Radiotherapy. Three different fractionation schedules were used for radiotherapy (Table I). Hyperfractionation with 1.7 Gy administered twice daily was used mostly from 2000 to 2008 , while conventional fractionation with 2 Gy daily dominated from 2009 onwards. A third fractionation schedule was used in 18 cases, mostly patients enrolled in the randomized ARTSCAN II study $(19,20)$.

Until 2008, the total radiation dose given in ERTN was 40.8 Gy with two daily fractions over two and a half weeks, or 46 to $50 \mathrm{~Gy}$ with one daily fraction over four and a half to five weeks. Due to the accelerated treatment in the hyperfractionation schedule, the doses were at the time considered to be radiobiologically equivalent. After 2009, the hyperfraction schedule was abandoned, and for tongue cancer the elective dose to the $\mathrm{cNO}$ neck was increased to $60 \mathrm{~Gy}$. This change was made because tongue cancer has a higher frequency of regional recurrences and less sensitivity to radiotherapy when compared to oropharyngeal cancer, and it was judged that a higher radiation dose was needed to eradicate subclinical disease. Since 2009, radiotherapy has mostly been given with intensity-modulated radiation therapy (IMRT) or volumetric modulated arc therapy (VMAT). In cases prescribed $68 \mathrm{~Gy}$ to the 
post-operative volumes, we have gradually introduced simultaneous integrated boost with a total dose of $54.4 \mathrm{~Gy}$ and $1.6 \mathrm{~Gy}$ per fraction, or a total dose of $61.2 \mathrm{~Gy}$ and $1.8 \mathrm{~Gy}$ per fraction to elective neck volumes. This corresponds to about $52.6 \mathrm{~Gy}$ and 60.2 Gy, respectively, with 2 Gy per fraction in tumour effect $(\alpha / \beta=10)$ according to the widely used LQ model for calculation of radiobiologically equivalent doses (21).

Statistical analysis. OS was measured from the date of diagnosis to time of death as recorded in the Swedish population register. Those alive were censored at the last follow up. DSS was measured from the date of diagnosis to time of death by oral cancer, censored at the last follow up or death by other causes. Death by oral cancer was defined as the patient having verified or suspected manifestations of oral cancer at the time of death. Finally, rRFS was measured from the date of diagnosis to regional recurrence, with or without concurrent relapse in other locations, censored at the last follow up or death. Clinical follow up was ended after five years. OS, DSS, and rRFS for the whole group and for subgroups were calculated using the Kaplan-Meier method, with the log-rank test for statistical significance. Cox proportional hazard analysis was used for multivariate analysis. $p$-Values, all two-sided, were considered statistically significant if equal to or less than 0.05 . Calculations were made using version 25.0 of IBM SPSS Statistics for Windows (IBM Corp, Armonk, NY, USA).

Ethical approval. The study was approved by the Ethics Committee in Uppsala, Sweden (ref: 2016/539; date: 18 January 2017).

\section{Results}

From the regional head and neck register in Örebro, 420 node-negative cases of OSCC in the period from January 1, 2000 to June 30, 2016 were identified. The most common subsite was cancer of the tongue, which made up almost half of the cases (45\%), followed by gingival cancer $(27.6 \%)$. In $81 \%$ of cases $(n=339)$, surgery was the primary treatment of the tumour, whereas in the remaining 19\% (80/420) another ablative treatment modality of the primary tumour site was used. Baseline characteristics and treatments are presented in Table II.

Median follow up was 10.5 years at the time of data analysis. For the whole cohort, the median age was 69 years and OS at three years and five years was $67 \%$ and $60 \%$, respectively. There was a significantly higher survival for lower T-stages (T1-T2) compared to higher T-stages (T3-T4). DSS at five years was 77\%, and was also significantly higher for lower T-stages. Data on OS, DSS, and rRFS are presented in Table III.

Of the 420 patients, $154(36.7 \%)$ had no elective treatment of the node-negative neck because the risk for regional recurrence was considered low. Of the remaining 266 patients, 129 (48.5\%) had ERTN as the only adjuvant treatment of the neck, and 137 (51.5\%) had END. Of the 137 patients that had END, $92(67.2 \%)$ also had postoperative RT to the neck. Data on OS, DSS, and rRFS for patients with or
Table III. Overall survival and disease-specific survival for subgroups.

\begin{tabular}{|c|c|c|c|}
\hline & All oral cancer & & $p$-Value \\
\hline $\begin{array}{l}\text { n } \\
\text { 5-year OS } \\
\text { 5-year DSS } \\
\text { 5-year rRFS }\end{array}$ & $\begin{array}{c}420 \\
59.7 \% \\
77.2 \% \\
83.5 \%\end{array}$ & & \\
\hline T-stage & $\mathrm{T} 1-2$ & T3-4 & \\
\hline $\begin{array}{l}\mathrm{n} \\
\text { 5-year OS } \\
\text { 5-year DSS } \\
\text { 5-year rRFS }\end{array}$ & $\begin{array}{c}298 \\
64.4 \% \\
81.2 \% \\
82.8 \%\end{array}$ & $\begin{array}{c}122 \\
48.1 \% \\
67.1 \% \\
85.6 \%\end{array}$ & $\begin{array}{c}0.001 \\
0.000 \\
\text { ns }\end{array}$ \\
\hline Sub-site & Tongue & Non-tongue & \\
\hline $\begin{array}{l}\text { n } \\
\text { 5-year OS } \\
\text { 5-year DSS } \\
\text { 5-year rRFS }\end{array}$ & $\begin{array}{c}189 \\
63.4 \% \\
76.9 \% \\
79.2 \%\end{array}$ & $\begin{array}{c}231 \\
56.1 \% \\
77.4 \% \\
85.4 \%\end{array}$ & $\begin{array}{c}\mathrm{ns} \\
\mathrm{ns} \\
0.045\end{array}$ \\
\hline Age & $\leq 70$ years & $>70$ years & \\
\hline $\begin{array}{l}\text { n } \\
\text { 5-year OS } \\
\text { 5-year DSS } \\
\text { 5-year rRFS }\end{array}$ & $\begin{array}{c}150 \\
72.7 \% \\
82.0 \% \\
80.8 \%\end{array}$ & $\begin{array}{c}270 \\
45.8 \% \\
71.5 \% \\
80.9 \%\end{array}$ & $\begin{array}{c}0.000 \\
0.014 \\
\mathrm{~ns}\end{array}$ \\
\hline Period & 2000-2008 & 2009-2016 & \\
\hline $\begin{array}{l}\text { n } \\
\text { 5-year OS } \\
\text { 5-year DSS } \\
\text { 5-year rRFS }\end{array}$ & $\begin{array}{c}186 \\
57.5 \% \\
76.1 \% \\
81.5 \%\end{array}$ & $\begin{array}{c}234 \\
60.7 \% \\
78.0 \% \\
85.1 \%\end{array}$ & $\begin{array}{l}\mathrm{ns} \\
\mathrm{ns} \\
\mathrm{ns}\end{array}$ \\
\hline Gender & Male & Female & \\
\hline $\begin{array}{l}\mathrm{n} \\
\text { 5-year OS } \\
\text { 5-year DSS } \\
\text { 5-year rRFS }\end{array}$ & $\begin{array}{c}209 \\
58.8 \% \\
76.5 \% \\
83.1 \%\end{array}$ & $\begin{array}{c}211 \\
60.5 \% \\
77.8 \% \\
82.3 \%\end{array}$ & $\begin{array}{l}\mathrm{ns} \\
\mathrm{ns} \\
\mathrm{ns}\end{array}$ \\
\hline
\end{tabular}

OS: Overall survival; DSS: disease-specific survival; rRFS: regional relapse-free survival.

without END, and T1-T2 versus T3-T4 disease, are presented in Figure 1.

OS was practically the same for ages up to 69 years, but as expected, it dropped at ages above 70 years. When the material was dichotomized into one group of $\leq 70$ years and one group of $>70$ years, there was a significant difference in OS and DSS, but not in rRFS, between the age groups (Table III).

Figure 2 presents Kaplan-Meier curves for patients that did or did not receive any RT as part of their primary treatment for OSCC. The material was dichotomized into an early period from 2000 to 2008 and a later period from 2009 

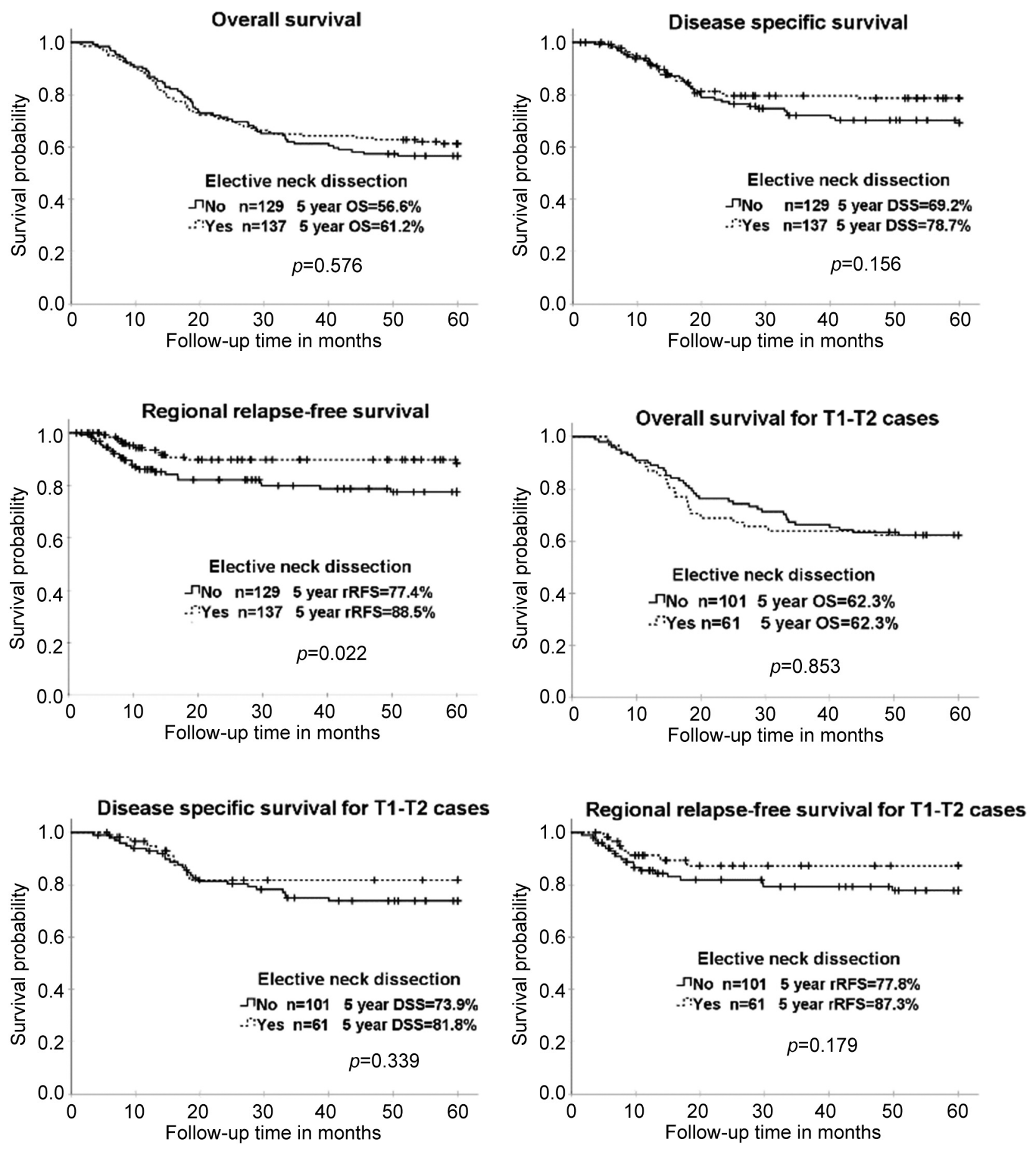

Figure 1. Continued

to 2016. Patients that had RT showed a trend towards increased rRFS in the later period, but there was no such trend for patients who did not have RT. None of the differences in outcome showed statistical significance according to the log-rank test. Figure 3 presents rRFS for patients with T1-T2 disease treated from 2009 onwards. This group showed no differences in rRFS correlated to whether END was administered or not. 

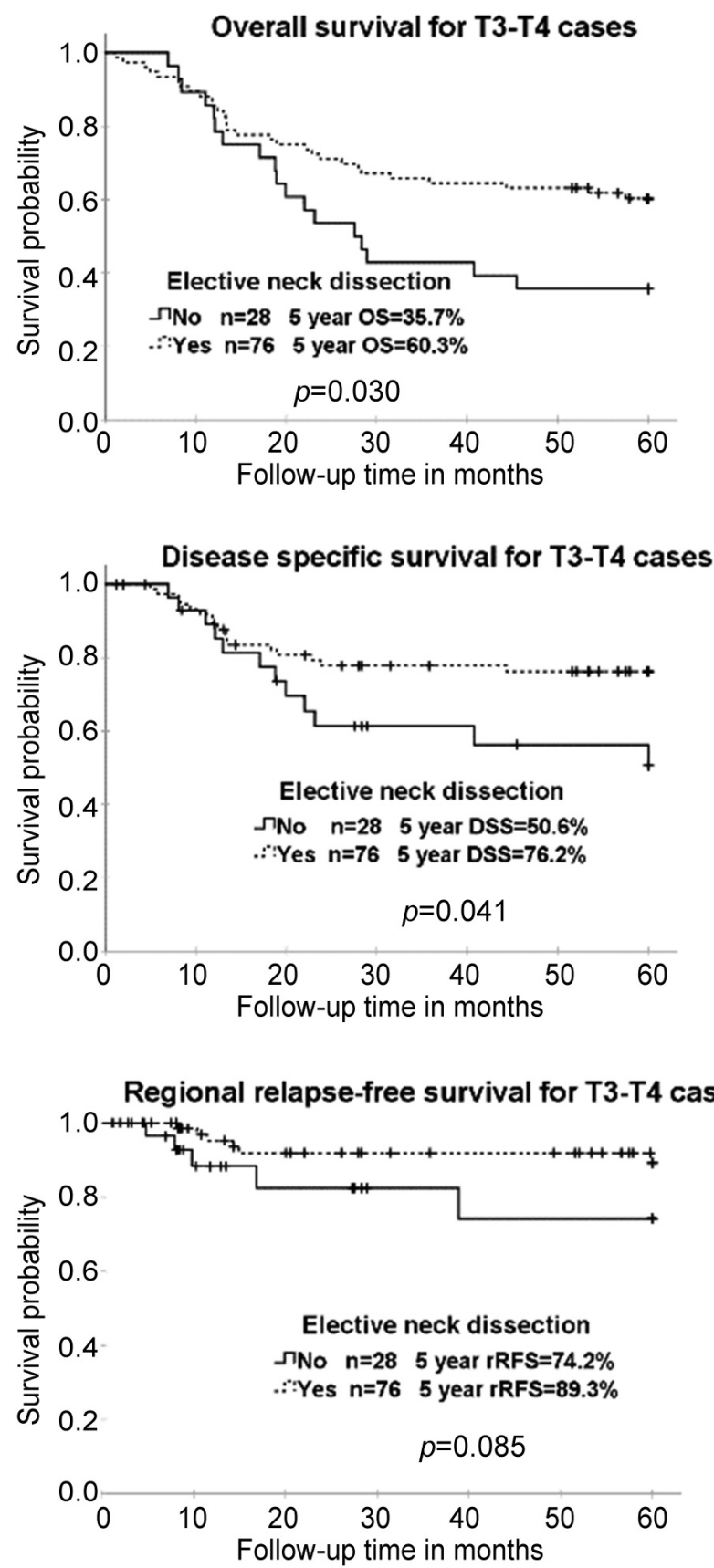

Figure 1. Survival for patients with active treatment of the NO neck. All patients who did not undergo elective neck dissection (END) underwent elective radiotherapy of the neck (ERTN). Patients who underwent END might also have undergone ERTN.

In the multivariate Cox regression analysis on the whole material, END was associated with a hazard ratio of 0.72 (95\% CI $=0.49-1.04)$ for OS and a hazard ratio of 0.48 (95\% CI=0.24-0.96) for regional relapse. Lower age and lower T-stage showed statistically significant correlations with increased OS but not with increased rRFS. In the subgroup treated during 2009-2016 with T1-T2 tumours, the hazard ratio associated with END was $0.92(95 \% \mathrm{CI}=0.29$ 2.94) for regional relapse.

\section{Discussion}

In this long-term follow-up study of 420 cases of nodenegative OSCC, ERTN with modern radiotherapy technique and radiation doses of 50-60 Gy seemed to be as effective as END in preventing regional relapses.

For the patients up to 69 years of age with early stage OSCC (T1-T2), survival was good and compared well with previously published results $(7,22)$. At ages of 70 and above, both OS and DSS fell rapidly, while the risk for regional recurrence did not appear to increase significantly with increasing age.

When looking at patients who received adjuvant treatment of the neck during the whole time span, we saw a significantly lower frequency of regional recurrence when END rather than ERTN was performed. However, the difference in DSS was smaller and not significant, and for OS the difference was practically non-existent. The benefit in rRFS for patients with END was also seen in the subgroup with T1-T2 tumours but here the difference was not significant. For the subgroup with T3-T4 tumours, we found a significant difference in OS in favour of END. However, this difference may have been at least partly because END in our material was linked to free flap surgery, which in most cases is the preferred choice for these patients with locally advanced tumours. It can therefore be assumed, that the group which did not undergo END contained a high proportion of patients who were too frail to undergo major surgery. Frailty and the consequent undertreatment can be assumed to have had a negative effect on survival in this patient group.

More interesting are the results in the later period. In the years since 2009, IMRT and VMAT have been used extensively in our region, and the prescribed radiation dose to adjuvant volumes in the neck increased during the same period as shown in Table I. In comparison to the earlier period, this later period showed an improvement in rRFS in the group that received radiation treatment, while rRFS seemingly remained unchanged over time in the group that did not receive radiation treatment. These findings should be interpreted with caution, as the change was not statistically significant. However, it could be an indication that improved radiotherapy technique and increased radiation dose may have led to improved outcomes.

For patients with T1-T2 N0 tumours who received active adjuvant treatment of the neck from 2009 onwards, we no longer saw any advantage for END compared to single mode ERTN, regarding DSS and rRFS. There were only 97 cases in this group, which is too few to draw any clear conclusions, 

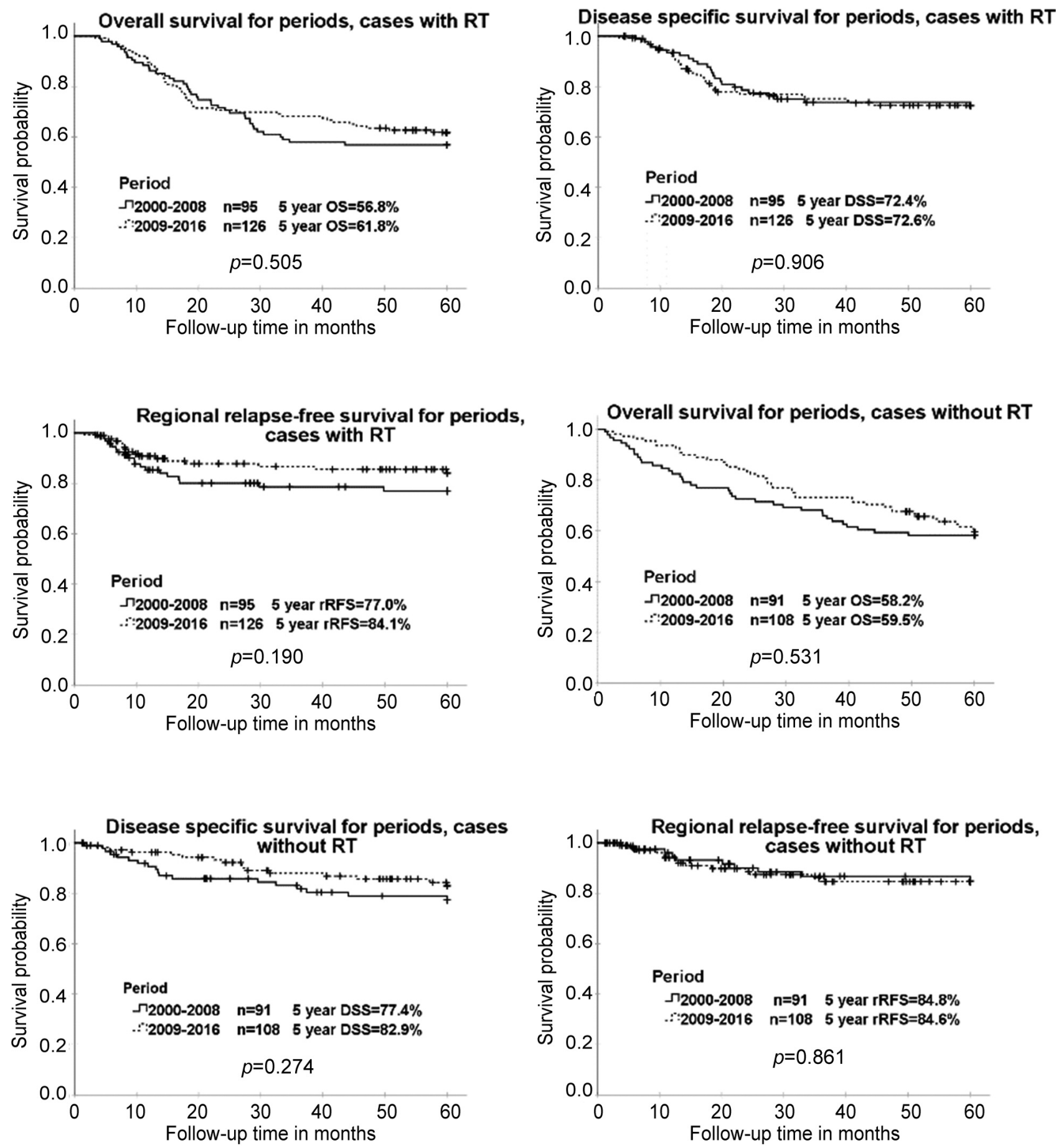

Figure 2. Survival for patients in different periods, with or without adjuvant radiotherapy (RT).

but it might indicate that if ERTN is given using a modern technique with adequate doses, END can safely be omitted.

According to the ASCO clinical practice guideline (23), END is preferred for patients in this situation, but radiotherapy is an alternative if surgery is not feasible. A retrospective study by Vergeer et al. (24) presented data on 619 head and neck cancer patients from 1985 to 2000 . Of the 372 who had OSCC, 265 received ERTN (46-50 Gy) while 107 underwent END, and the three-year regional control rates were $94.6 \%$ and $100 \%$, respectively. It is unclear if this difference was 
statistically significant. Multivariate analysis on all 619 head and neck cancer patients showed a significant benefit for END over ERTN, with a hazard ratio of 4.81 (95\% CI=1.68-13.8) regarding neck control. Less than half of the patients in the multivariate analysis had OSCC.

Several retrospective studies on definitive chemoradiotherapy for OSCC have reported low incidence of regional recurrence (25-27), indicating that chemoradiation might be an effective treatment of microscopic cancer spread to lymph nodes. The results of the present study further strengthen the case that ERTN is an effective treatment, and that it might be a viable alternative to END.

Another important topic to consider when comparing END and ERTN is the side effects. Data on complications and quality of life are not recorded in this register, but side effects are known from clinical practice and literature. Postoperative radiotherapy of OSCC causes acute side effects such as mucositis, pain, and nutrition problems, and in the longer term there is risk of fibrosis, osteoradionecrosis, and dysphagia $(28,29)$. For the most part, however, these side effects are attributed to the radiation delivered to the postoperative region in the oral cavity, and not to radiation to the elective neck volumes. Organs at risk in ERTN are the salivary glands, thyroid gland, blood vessels, muscles, and soft tissue of the neck. Central structures such as the larynx, trachea, and oesophagus are usually spared from high doses with the IMRT technique. Function of the parotid glands can also often be preserved (30), but the submandibular glands often receive doses exceeding the tolerance. Late side effects also include risk of hypothyroidism (31), and irradiation of the carotid vessels increases the risk of carotid artery stenosis and stroke (32) but the frequency of stroke seems to be low.

Complications after neck dissection include short-term complications such as bleeding, seroma, chylous fistula, infection, and post-operative pain, as well as long-term complications most often related to nerve damage. The marginal branch of the facial nerve and the spinal accessory nerve are particularly exposed to damage, leading to impaired function of the depressor muscle and the trapezius muscle, respectively (33-35). In most cases of END, the ipsilateral submandibular gland is removed. END also leaves a visible scar, which might be considered both a lasting cosmetic impairment and a reminder for the patient of the disease.

The side-effects of both ERTN and END are mainly of a manageable nature, and for most patients they will be of minor importance compared to the consequences of the surgery of the primary tumour and the radiotherapy to the oral cavity. It is thus not obvious whether END or ERTN would be preferable from the patient's point of view.

Sentinel node biopsy is becoming widely used as a staging procedure for $\mathrm{cNO}$ OSCC, especially for tongue cancer. A positive sentinel node biopsy is today often followed by a neck dissection, though ERTN administered along with
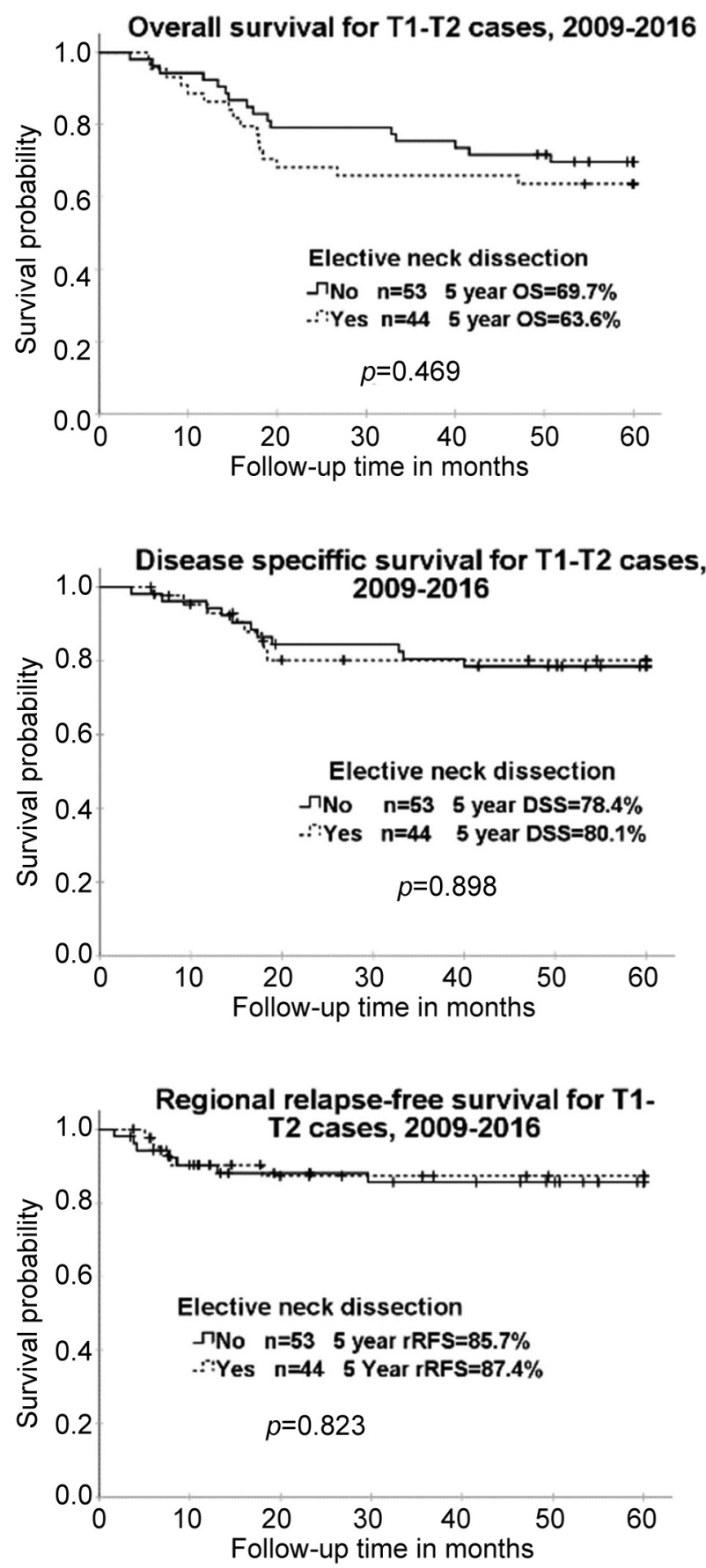

Figure 3. Survival for patients with active treatment of the NO neck with T1-T2 tumour during 2009-2016. All patients who did not undergo elective neck dissection END underwent elective radiotherapy of the neck (ERTN). Patients who underwent END might also have undergone ERTN.

postoperative radiation of the primary tumour site would be a convenient alternative for the patient as well as for the health care provider. Future research will show if radiotherapy could be a good alternative to lymph node 
dissection after a positive sentinel node, as has been the case with breast cancer (36).

A strength of this study is that it is based on a large, consecutive, and unselected patient material that has been followed for a long time. Another is that we were able to compare treatment with END and ERTN, as both treatment modalities are used at our centre, albeit in somewhat different situations. A limitation is that this was a retrospective study with the difficulties involved in adjusting for systematic errors. There are also difficulties in interpreting the results, as the groups that received END and ERTN are not obviously comparable. As can be seen in Table II, for example, tongue cancer was more common in the group that had ERTN, whereas gingival cancer was more common in the group that had END.

Elective treatment of the neck with radiotherapy to an adequate dose (50-60 Gy) and with a modern technique is effective in early-stage oral cancer, and might be equally effective as END in preventing regional relapse. However, a prospective randomized study is needed to determine whether END can safely be replaced with ERTN as standard treatment.

\section{Conflicts of Interest}

The Authors report no conflicts of interest in relation to this study.

\section{Authors' Contributions}

Study design: Lundin, Reizenstein, Ahlgren, Lennernäs, Bergqvist; Data collection: Lundin, Reizenstein, Landström; Data processing: Lundin, Reizenstein, Ahlgren, Lennernäs, Bergqvist, Landström; Article preparation and review: Lundin, Reizenstein, Ahlgren, Lennernäs, Bergqvist, Landström.

\section{Acknowledgements}

This work was supported by funding from Region Örebro Län and Örebro University, Örebro, Sweden.

\section{References}

1 De Zinis LO, Bolzoni A, Piazza C and Nicolai P: Prevalence and localization of nodal metastases in squamous cell carcinoma of the oral cavity: role and extension of neck dissection. Eur Arch Otorhinolaryngol 263(12): 1131-1135, 2006. PMID: 17004089. DOI: $10.1007 / \mathrm{s} 00405-006-0128-5$

2 El-Naaj IA, Leiser Y, Shveis M, Sabo E and Peled M: Incidence of oral cancer occult metastasis and survival of T1-T2N0 oral cancer patients. J Oral Maxillofac Surg 69(10): 2674-2679, 2011. PMID: 21571415. DOI: 10.1016/j.joms.2011.02.012

3 Feng Z, Li JN, Li CZ and Guo CB: Elective neck dissection versus observation in the management of early tongue carcinoma with clinically node-negative neck: a retrospective study of 229 cases. J Craniomaxillofac Surg 42(6): 806-810, 2014. PMID: 24529348. DOI: 10.1016/j.jcms.2013.11.016
4 Weiss MH, Harrison LB and Isaacs RS: Use of decision analysis in planning a management strategy for the stage N0 neck. Arch Otolaryngol Head Neck Surg 120(7): 699-702, 1994. PMID: 8018319. DOI: 10.1001/archotol.1994.01880310005001

5 Ivaldi E, Di Mario D, Paderno A, Piazza C, Bossi P, Iacovelli NA, Incandela F, Locati L, Fallai C and Orlandi E: Postoperative radiotherapy (PORT) for early oral cavity cancer (pT1-2,N0-1): A review. Crit Rev Oncol Hematol 143: 67-75, 2019. PMID: 31499275. DOI: 10.1016/j.critrevonc.2019.08.003

6 Peters LJ, Goepfert H, Ang KK, Byers RM, Maor MH, Guillamondegui O, Morrison WH, Weber RS, Garden AS and Frankenthaler RA: Evaluation of the dose for postoperative radiation therapy of head and neck cancer: first report of a prospective randomized trial. Int J Radiat Oncol Biol Phys 26(1): 3-11, 1993. PMID: 8482629. DOI: 10.1016/0360-3016(93)90167-t

7 D'Cruz AK, Vaish R, Kapre N, Dandekar M, Gupta S, Hawaldar R, Agarwal JP, Pantvaidya G, Chaukar D, Deshmukh A, Kane S, Arya S, Ghosh-Laskar S, Chaturvedi P, Pai P, Nair S, Nair D, Badwe $\mathrm{R}$ and Head and Neck Disease Management Group: Elective versus therapeutic neck dissection in node-negative oral cancer. N Engl J Med 373(6): 521-529, 2015. PMID: 26027881. DOI: 10.1056/NEJMoa1506007

8 Hegde P, Roy S, Shetty T, Prasad BR and Shetty U: Tumor infiltration depth as a prognostic parameter for nodal metastasis in oral squamous cell carcinoma. Int J Appl Basic Med Res 7(4): 252-257, 2017. PMID: 29308364. DOI: 10.4103/ijabmr.IJABMR_66_17

9 Bur AM, Lin A and Weinstein GS: Adjuvant radiotherapy for early head and neck squamous cell carcinoma with perineural invasion: A systematic review. Head Neck 38 Suppl 1: E2350E2357, 2016. PMID: 26613965. DOI: 10.1002/hed.24295

10 Tarsitano A, Tardio ML and Marchetti C: Impact of perineural invasion as independent prognostic factor for local and regional failure in oral squamous cell carcinoma. Oral Surg Oral Med Oral Pathol Oral Radiol 119(2): 221-228, 2015. PMID: 25487983. DOI: 10.1016/j.oooo.2014.10.004

11 Yang X, Tian X, Wu K, Liu W, Li S, Zhang Z and Zhang C: Prognostic impact of perineural invasion in early stage oral tongue squamous cell carcinoma: Results from a prospective randomized trial. Surg Oncol 27(2): 123-128, 2018. PMID: 29937161. DOI: 10.1016/j.suronc.2018.02.005

12 Kreppel M, Nazarli P, Grandoch A, Safi AF, Zirk M, Nickenig HJ, Scheer M, Rothamel D, Hellmich M and Zöller JE: Clinical and histopathological staging in oral squamous cell carcinoma Comparison of the prognostic significance. Oral Oncol 60: 68-73, 2016. PMID: 27531875. DOI: 10.1016/j.oraloncology.2016.07.004

13 Liao CT, Lin CY, Fan KH, Wang HM, Ng SH, Lee LY, Hsueh C, Chen IH, Huang SF, Kang CJ and Yen TC: Identification of a highrisk group among patients with oral cavity squamous cell carcinoma and pT1-2N0 disease. Int J Radiat Oncol Biol Phys 82(1): 284-290, 2012. PMID: 21075550. DOI: 10.1016/j.jijrobp.2010.09.036

14 Huang SH, Hwang D, Lockwood G, Goldstein DP and O'Sullivan B: Predictive value of tumor thickness for cervical lymph-node involvement in squamous cell carcinoma of the oral cavity: a meta-analysis of reported studies. Cancer 115(7): 14891497, 2009. PMID: 19197973. DOI: 10.1002/cncr.24161

15 Lundin E, Bergqvist M, Ahlgren J, Reizenstein J and Lennernäs BO: Validation of a clinical cancer register at the Head and Neck Oncology Center in Örebro. Anticancer Res 39(1): 285-289, 2019. PMID: 30591470. DOI: 10.21873/anticanres.13109 
16 Sobin LH, Gospodarowicz MK and Wittekind C: Tnm classification of malignant tumors, seventh edition. Wiley-Blackwell, 2009.

17 Landström FJ, Nilsson CO, Reizenstein JA, Nordqvist K, Adamsson GB and Löfgren AL: Electroporation therapy for T1 and T2 oral tongue cancer. Acta Otolaryngol 131(6): 660-664, 2011. PMID: 21190422. DOI: 10.3109/00016489.2010.541937

18 Landström FJ, Reizenstein J, Adamsson GB, Beckerath Mv and Möller C: Long-term follow-up in patients treated with curative electrochemotherapy for cancer in the oral cavity and oropharynx. Acta Otolaryngol 135(10): 1070-1078, 2015. PMID: 26061895. DOI: $10.3109 / 00016489.2015 .1049663$

19 Zackrisson B, Kjellén E, Söderström K, Brun E, Nyman J, Friesland S, Reizenstein J, Sjödin H, Ekberg L, Lödén B, Franzén L, Ask A, Wickart-Johansson G, Lewin F, Björk-Eriksson T, Lundin E, Dalianis T, Wennerberg J, Johansson KA and Nilsson P: Mature results from a Swedish comparison study of conventional versus accelerated radiotherapy in head and neck squamous cell carcinoma - The ARTSCAN trial. Radiother Oncol 117(1): 99-105, 2015. PMID: 26427805. DOI: 10.1016/j.radonc.2015.09.024

20 Zackrisson B, Nilsson P, Kjellén E, Johansson KA, Modig H, Brun E, Nyman J, Friesland S, Reizenstein J, Sjödin H, Ekberg L, Lödén B, Mercke C, Fernberg JO, Franzén L, Ask A, Persson E, WickartJohansson G, Lewin F, Wittgren L, Björ O and Björk-Eriksson T: Two-year results from a Swedish study on conventional versus accelerated radiotherapy in head and neck squamous cell carcinoma - the ARTSCAN study. Radiother Oncol 100(1): 41-48, 2011. PMID: 21295880. DOI: 10.1016/j.radonc.2010.12.010

21 Fowler JF: The linear-quadratic formula and progress in fractionated radiotherapy. Br J Radiol 62(740): 679-694, 1989. PMID: 2670032. DOI: 10.1259/0007-1285-62-740-679

22 Hutchison IL, Ridout F, Cheung SMY, Shah N, Hardee P, Surwald C, Thiruchelvam J, Cheng L, Mellor TK, Brennan PA, Baldwin AJ, Shaw RJ, Halfpenny W, Danford M, Whitley S, Smith G, Bailey MW, Woodwards B, Patel M, McManners J, Chan CH, Burns A, Praveen P, Camilleri AC, Avery C, Putnam G, Jones K, Webster K, Smith WP, Edge C, McVicar I, Grew N, Hislop S, Kalavrezos N, Martin IC and Hackshaw A: Nationwide randomised trial evaluating elective neck dissection for early stage oral cancer (SEND study) with meta-analysis and concurrent real-world cohort. Br J Cancer 121(10): 827-836, 2019. PMID: 31611612. DOI: 10.1038/s41416-019-0587-2

23 Koyfman SA, Ismaila N, Crook D, D’Cruz A, Rodriguez CP, Sher DJ, Silbermins D, Sturgis EM, Tsue TT, Weiss J, Yom SS and Holsinger FC: Management of the neck in squamous cell carcinoma of the oral cavity and oropharynx: ASCO Clinical Practice Guideline. J Clin Oncol 37(20): 1753-1774, 2019. PMID: 30811281. DOI: 10.1200/JCO.18.01921

24 Vergeer MR, Doornaert PAH, de Bree R, Leemans CR, Slotman BJ and Langendijk JA: Postoperative elective nodal irradiation for squamous cell carcinoma of the head and neck: outcome and prognostic factors for regional recurrence. Ann Oncol 22(11): 24892494, 2011. PMID: 21363877. DOI: 10.1093/annonc/mdq768

25 Foster CC, Melotek JM, Brisson RJ, Seiwert TY, Cohen EEW, Stenson KM, Blair EA, Portugal L, Gooi Z, Agrawal N, Vokes EE and Haraf DJ: Definitive chemoradiation for locally-advanced oral cavity cancer: A 20-year experience. Oral Oncol 80: 16-22, 2018. PMID: 29706184. DOI: 10.1016/j.oraloncology.2018.03.008

26 Scher ED, Romesser PB, Chen C, Ho F, Wuu Y, Sherman EJ, Fury MG, Wong RJ, McBride S, Lee NY and Riaz N: Definitive chemoradiation for primary oral cavity carcinoma: A single institution experience. Oral Oncol 51(7): 709-715, 2015. PMID: 25958830. DOI: 10.1016/j.oraloncology.2015.04.007

27 Murthy V, Agarwal JP, Laskar SG, Gupta T, Budrukkar A, Pai P, Chaturvedi P, Chaukar D and D'Cruz A: Analysis of prognostic factors in 1180 patients with oral cavity primary cancer treated with definitive or adjuvant radiotherapy. J Cancer Res Ther 6(3): 282-289, 2010. PMID: 21119254. DOI: 10.4103/0973-1482.73360

28 Sroussi HY, Epstein JB, Bensadoun RJ, Saunders DP, Lalla RV, Migliorati CA, Heaivilin N and Zumsteg ZS: Common oral complications of head and neck cancer radiation therapy: mucositis, infections, saliva change, fibrosis, sensory dysfunctions, dental caries, periodontal disease, and osteoradionecrosis. Cancer Med 6(12): 2918-2931, 2017. PMID: 29071801. DOI:10.1002/cam4.1221

29 Söderström K, Nilsson P, Laurell G, Zackrisson B and Jäghagen EL: Dysphagia - Results from multivariable predictive modelling on aspiration from a subset of the ARTSCAN trial. Radiother Oncol 122(2): 192-199, 2017. PMID: 27687824. DOI: 10.1016/j.radonc 2016.09 .001

30 van Rij CM, Oughlane-Heemsbergen WD, Ackerstaff AH, Lamers EA, Balm AJ and Rasch CR: Parotid gland sparing IMRT for head and neck cancer improves xerostomia related quality of life. Radiat Oncol 3: 41, 2008. PMID: 19068126. DOI: $10.1186 / 1748-717 X-3-41$

31 Fujiwara M, Kamikonya N, Odawara S, Suzuki H, Niwa Y, Takada Y, Doi H, Terada T, Uwa N, Sagawa K and Hirota S: The threshold of hypothyroidism after radiation therapy for head and neck cancer: a retrospective analysis of 116 cases. J Radiat Res 56(3): 577-582, 2015. PMID: 25818629. DOI: 10.1093/jrr/rrv006

32 Gujral DM, Chahal N, Senior R, Harrington KJ and Nutting CM: Radiation-induced carotid artery atherosclerosis. Radiother Oncol 110(1): 31-38, 2014. PMID: 24044796. DOI: 10.1016/ j.radonc.2013.08.009

33 Kuntz AL and Weymuller EA Jr: Impact of neck dissection on quality of life. Laryngoscope 109(8): 1334-1338, 1999. PMID: 10443845. DOI: 10.1097/00005537-199908000-00030

34 Gane EM, Michaleff ZA, Cottrell MA, McPhail SM, Hatton AL, Panizza BJ and O'Leary SP: Prevalence, incidence, and risk factors for shoulder and neck dysfunction after neck dissection: A systematic review. Eur J Surg Oncol 43(7): 1199-1218, 2017. PMID: 27956321. DOI: 10.1016/j.ejso.2016.10.026

35 McDonald C, Lowe D, Bekiroglu F, Schache A, Shaw R and Rogers SN: Health-related quality of life in patients with T1N0 oral squamous cell carcinoma: selective neck dissection compared with wait and watch surveillance. Br J Oral Maxillofac Surg 57(7): 649654, 2019. PMID: 31230853. DOI: 10.1016/j.bjoms.2019.05.021

36 Donker M, van Tienhoven G, Straver ME, Meijnen P, van de Velde CJ, Mansel RE, Cataliotti L, Westenberg AH, Klinkenbijl JH, Orzalesi L, Bouma WH, van der Mijle HC, Nieuwenhuijzen GA, Veltkamp SC, Slaets L, Duez NJ, de Graaf PW, van Dalen T, Marinelli A, Rijna H, Snoj M, Bundred NJ, Merkus JW, Belkacemi Y, Petignat P, Schinagl DA, Coens C, Messina CG, Bogaerts J and Rutgers EJ: Radiotherapy or surgery of the axilla after a positive sentinel node in breast cancer (EORTC 1098122023 AMAROS): a randomised, multicentre, open-label, phase 3 non-inferiority trial. Lancet Oncol 15(12): 1303-1310, 2014. PMID: 25439688. DOI: 10.1016/S1470-2045(14)70460-7

Received April 27, 2021

Revised May 12, 2021

Accepted May 13, 2021 